\title{
Hak dan Status Anak Syubhat dalam Penikahan
}

\author{
Oleh: \\ Fahmi Al Amruzi \\ Fakultas Syariah dan Ekonomi Islam \\ Universitas Islam Negeri Antasari Banjarmasin \\ e-mail: fahmialamruzi@yahoo.co.id
}

\begin{abstract}
Allah has clearly established all good things that are lawful (halal) or forbidden (haram), and between them there is something called syubhat, where most people fall into it and they do not know whether it is halal or haram. If you do not know whether it is halal or haram will a thing, then will arise a phenomenon called as syubhat. A relationship that was made because there is an element of syubhat, whether that happens to a marriage, called syubhat and then to be fasakh, or occurs in watha' which is also called watha' syubhat and consequently bear a child, the child is then called also with "a syubbat child." Nasab (bloodline or lineage) of a syubhat child, whether resulting from a watha 'syubbat or a syubhat marriage, is set to his father, or a person who has become his/ her watha', because a marriage whether it is shabih or fasid, the nasab (lineage) of a child will remains to his/ her watha', not to his mother, because the Islamic law for a syubhat child is different from that of the illegitimate child.
\end{abstract}

Keywords: Syubhat Marriage, Watha' Syubhat, Syubhat Child, Illegitimate Child.

Abstrak: Allah sudah menetapkan semua perkara baik yang halal atau haram jelas dan diantara keduanya ada sesuatu yang disebut syubhat, dimana kebanyakan manusia terjerumus ke dalamnya dan mereka tidak tahu apakah itu halal atau haram. Apabila tidak tahu halal dan haram suatu hal, maka akan timbul suatu penyakit yaitu syubhat. Sebuah hubungan yang dilakukan karena ada sebuah unsur syubhat, baik yang terjadi pada sebuah pernikahan yang disebut syubhat dan kemudian difasakh, atau terjadi pada watha' yang disebut juga watha' syubhat dan akibatnya melahirkan seorang anak, anak tersebut pun kemudian disebut pula dengan anak syubhat. Nasab anak syubhat baik yang dihasilkan dari watha' yang syubhat atau pernikahan Syubhat tetap kepada bapaknya, atau seorang yang telah mewatha'nya. Karena baik nikah shahih atau fasid nasab anak tetap kepada seorang yang mewatha'nya bukan kepada ibunya, karena anak syubhat hukumnya berbeda dengan anak zina.

Kata kunci: Nikah syubhat, Watha' syubhat, Anak syubhat, Anak zina

\section{Pendahuluan}

Perkawinan dikatakan sah apabila memenuhi segala ketentuan yang sudah ditetapkan dalam Islam. Ketentuan tersebut meliputi syarat-syarat dan rukunrukun tertentu sesuai dengan syariat agama
Islam sebagaimana diterangkan secara tegas pada pasal 2 ayat 1 Undang-Undang Perkawinan Nomor 1 Tahun 1974 dijelaskan bahwa "Perkawinan adalah sah, apabila dilakukan menurut hukum masing- 
masing agamanya dan kepercayaannya itu". 1

Dapat dipahami bahwa hukum agama memegang peranan yang sangat penting dalam menentukan keabsahan suatu perkawinan, dan sebagai akibat dari perkawinan yang sah menurut Islam adalah bahwa setiap anak akibat perkawinan tersebut berstatus sebagai anak yang sah bagi kedua orang tua yang melahirkannya, sebagaimana diterangkan pada pasal 42 Undang-Undang Perkawinan Nomor 1 Tahun 1974 yang berbunyi “Anak yang sah adalah anak yang dilahirkan dalam atau sebagai akibat perkawinan yang sah." 2 Oleh karena itu, orang tua memiliki kewajiban dalam memberikan nafkah baik jasmani maupun rohani kepada isteri dan anaknya.

Sebaliknya anak yang lahir diluar perkawinan yang sah maka bukanlah anak yang sah, sebagaimana dijelaskan dalam pasal 42 dan 43 Undang-Undang Nomor 1 Tahun 1974 Tentang Perkawinan:

Pasal 42:

Anak yang sah adalah anak yang dilahirkan dalam atau sebagai akibat perkawinan yang sah.

1 Undang-Undang Republik Indonesia Nomor 1 Tahun 1974 Tentang Perkawinan, Bandung: Citra Umbara, 2008, hal. 2.

2 Ibid, h. 17.

3 Ibid., h. 17.

4 Departemen Agama RI. Kompilasi Hukum Islam, Direktorat Jenderal Pembinaan Kelembagaan Agama Islam, Jakarta: 1998, hal. 263

\section{Fahmi Al-Amruzi}

Pasal 43:

Anak yang dilahirkan di luar perkawinan hanya mempunyai hubungan perdata dengan ibunya dan keluarga ibunya. ${ }^{3}$

Kedua pasal di atas memberikan pernjelasan bahwa anak yang sah hanya didapat jika terlahir melalui perkawinan yang sah. Demikian juga Kompilasi Hukum Islam (KHI) pasal 99 yang menyatakan : " anak sah adalah : (a) anak yang lahir dalam atau sebagai akibat perkawinan yang sah. (b) Hasil pembuahan suami istri yang sah di luar rahim dan

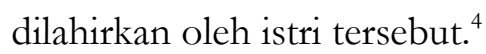

Sementara anak yang lahir akibat bukan dari zina tetapi dari kekeliruan; apakah kekeliruan saat bersetubuh dengan isteri/suami padahal bukan isteri/suaminya atau kekeliruan akibat salah wali atau nikah dengan perempuan yang haram untuk dinikahi apakah termasuk anak yang sah atau tidak, ataukah termasuk anak syubhat; akibat pernikahan atau persetubuhan yang terjadi akibat pelaku benar-benar tidak tahu bahwa wanita itu haram untuk dinikahi atau disetubuhi karena bukan isterinya. ${ }^{5}$

\footnotetext{
Muhammad Jawad Mughniyah, al-Figh 'ala alMadrabib al-Khamsah, diterjemahkan oleh Masykur A.B., Afif Muhammad, dan Idrus alKaff dengan judul: Fiqib Lima Maz̧bab, Lentera, Jakarta:, 2010, hal. 389.
} 
Tulisan ini akan mencoba menganalisa dan menjelaskan tentang persoalan anak syubhat yang lahir akibat dari nikah atau persetubuhan yang syubhat.

\section{Pengertian}

1. Nikah

Kata nikah berasal dari bahasa Arab nikeaaban yang merupakan masdar atau kata asal dari kata kerja nakaha. Sinonimnya tarawwaja kemudian diterjemahkan ke dalam bahasa Indonesia sebagai perkawinan. ${ }^{6}$ Menurut bahasa, nikah berarti penggabungan dan percampuran. Kata nikah juga berarti menyatu dan bersetubuh. ${ }^{8}$

Perkawinan menurut hukum Islam adalah pernikahan, yaitu akad yang sangat kuat atau mitsaqan ghalizan untuk mentaati perintah Allah dan melaksanakannya merupakan ibadah. ${ }^{9}$

Menurut istilah syariat Islam, Beni Ahmad Saebani memberikan pengertian bahwa pernikahan atau perkawinan adalah akad yang menghalalkan pergaulan dan membatasi hak dan kewajiban antara seorang laki-laki dengan seorang perempuan yang bukan mahram. ${ }^{10}$ Syekh

6 Rahmat Hakim, Hukum Perkawinan Islam, Bandung: CV. Pustaka Setia, 2000, hal. 11.

7 Syekh Hasan Ayyub, Op cit, hal. 29

8 Segaf Hasan Baharun, Bagaimanakah Anda Menikah dan Mengatasi Permasalahannya, (Pasuruan: Yayasan Pondok Pesantren Darullughah Wadda'wah, 2005), h. 1.

9 Departemen Agama RI. Op cit, hal. 14.

\section{Fahmi Al-Amruzi}

Hasan Ayyub pun menyatakan bahwa pernikahan merupakan akad antara pihak laki-laki dan pihak perempuan yang karenanya hubungan badan menjadi halal. ${ }^{11}$ Lebih lanjut, Rahmat Hakim memberikan pengertian mengenai nikah dengan suatu akad (perjanjian) yang mengandung kebolehan melakukan hubungan seksual dengan memakai katakata (lafaz) nikah atau tazwij. ${ }^{12}$

\section{Syubhat}

- Syubhat secara bahasa berasal dari kata yang artinya sesuatu yang menyerupai sesuatu, yaitu menyerupai dalam sifatnya. Sedangkan syubhat artinya samar atau tidak jelas. Suatu perkara yang samar yang hampir serupa. Atau sesuatu yang serupa antara satu dengan yang lainnya. ${ }^{13}$

- Syubhat secara istilah adalah segala sesuatu yang belum ada keyakinan halal atau haram didalamnya. Atau sesuatu yang belum diketahui halal dan haram secara hakiki. Atau sesutau yang masih samar apakah telah menjadi ketetapan atau belum. ${ }^{14}$

3. Watha' atau Wath' secara bahasa berjalan atau melalui. Sedangkan al

10 Beni Ahmad Saebani, Fiqh Munakahat 1, Bandung: CV. Pustaka Setia, 2001, hal. 9.

11 Syekh Hasan Ayyub, op cit. Hal. 29

12 Rahmat Hakim, op. Cit., h. 12.

13 Ibnu Mandur, Lisanul Arab, Darul Ma'arif, Kairo, hal. 2190

14 Kementerian Agama Kuwait, Al Mausu'ah Al Fiqhiyah Al Kuwaitiyah, Juz 25, Cet 1, Darus Sahofwah, 1992, hal. 338 
wath'u artinya setubuh, yang memiliki arti sama dengan jima'. ${ }^{15}$

4. Jima' Secara bahasa berasal dari kata jama'a yang artinya mengumpulkan sesuatu yang terpisah sehingga menjadi terkumpul. Sedangkan mujama'ah atau jima' adalah sebuah kiasan yang digunakan untuk menunjukkan pernikahan. ${ }^{16}$

5. Nikah Syubhat

Syaikh Sholeh al-Azhari

mendefinisikan nikah syubhat sebagai

berikut:

نكاح الثبهة أن ينكح نكاحا فاسدا مجمعا على فساده،

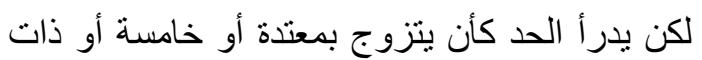

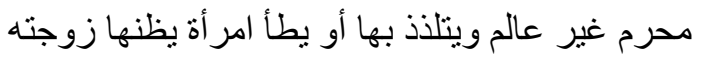

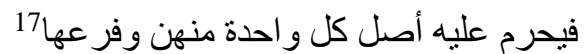

Artinya:

"Nikah Syubhat adalah ia menikah dengan pernikahan yang fasad/rusak/ tidak sah, yang telah disepakati/ijmak akan fasidnya, akan tetapi hukum had ditolak (tidak ditegakkan, seperti ia menikah dengan seorang wanita yang masih dalam masa 'iddah, atau dengan istri yang kelima, atau dengan wanita yang masih merupakan mahramnya, dalam kondisi ia tidak mengetahui hal tersebut dan ia telah berledzat-ledzat dengannya, atau ia

15 Mm AW Munawwir, Al Munawwir Kamus Arab-Indonesia, Pustaka Progressif, Yogyakarta, 1984, hal. 1566

16 Ibnu Mandur, Op cit, hal. 681

17 Sholeh bin Abids Samii' Al-Aaabi Al-Azhari Al Aabi Al Azhari, Ats-Tsamr Ad-Daani fi Tqriib al-Ma'aani, syarh Risaalah Ibni Abi Zaid Al- menjimak seorang wanita yang ia sangka adalah istrinya. Maka diharamkan baginya asal dan furu' dari setiap wanita tersebut"

6. Anak Syubhat

Anak syubhat adalah anak yang lahir dari suatu hubungan badan antara seorang laki-laki dengan seorang perempuan atas dasar kekeliruan ${ }^{18}$

Kesyubhatan terjadi dimungkin oleh dua hal: syubhat dalam akad, dan syubhat dalam tindakan (perbuatan).

a. Syubhat dalam akad, adalah manakala seorang laki-laki melaksanakan akad nikah dengan seorang wanita seperti halnya dengan akad nikah sah lainnya, tapi kemudian ternyata bahwa akadnya tersebut fasid karena satu dan lain alasan.

b. Syubhat dalam tindakan (perbuatan), yakni manakala seorang laki-laki mencampuri seorang wanita tanpa adanya akad antara mereka berdua, baik sah maupun fasid, semata-mata karena tidak sadar ketika melakukannya, atau dia meyakini bahwa wanita tersebut adalah halal untuk dicampuri, tapi kemudian ternyata bahwa wanita itu adalah wanita yang haram dicampuri.

Qoyrowaani, Mushthofa Al-Baabiy Al-Halabi, tahun $1338 \mathrm{H}$ hal. 352

D.Y. Witanto, Hukum Keluarga Hak dan Kedudukan Anak. Luar kawin, Jakarta: Prestasi Pustaka Publisher, 2012, h. 47-48 
Termasuk dalam kategori ini adalah hubungan seksual yang dilakukan orang gila, orang mabuk dan orang mengigau, serta orang yang yakin bahwa orang yang dia campuri itu adalah isterinya, tapi kemudian ternyata wanita itu bukan isterinya. ${ }^{19}$

\section{Status Anak Syubhat}

Setiap anak yang lahir adalah suci, Nabi SAW. bersabda dalam sebuah hadits yang diriwayatkan oleh Bukhari dan Muslim:

$$
\text { قال النبي صلى الله عليه و سلم: كل مولود يولد على الفطرة فأبو اه يهودانه أو ينصر انه أو يمجسانه }
$$

Artinya: Setiap anak dilahirkan dlm keadaan fitrah (Islam), maka kedua orang tuanyalah yg menjadikannya Yahudi, Nashrani atau Majusi.

Seorang anak yang lahir tidak dibebani dosa orang tuanya, Allah berfirman dalam surah al An'am ayat 164:

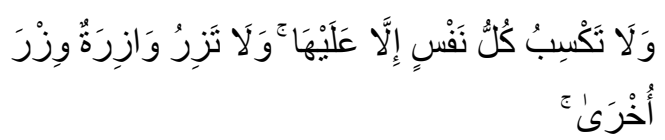

Artinya: Dan tidaklah seorang membuat dosa melainkan kemudharatannya kembali kepada dirinya sendiri; dan seorang yang

19 Muhammad Jawad Mughniyah, al-Figh 'ala alMadrabib al-Khamsah, diterjemahkan oleh Masykur A.B., Afif Muhammad, dan Idrus al- berdosa tidak akan memikul dosa orang lain.

Anak yang lahir diluar nikah atau yan g lahir dari persetubuhan syubhat adalah anak yang tidak berdosa karena itu tidak ada anak yang dilahirkan ke dunia berstatus haram, seorang anak tidak dibebani dosa atau kesalahan orang tuanya, dosa dan kesalahan orang tuanya hanya ditanggung oleh orang tuanya.

Ada kesalahan yang terjadi karena kekeliruan; baik kekeliruan pada pernikahan maupun keliru pada persetubuhan yang juga berakibat lahirnya seoran anak. Anak yang lahir akibat dari perkawinan yang difasakh akibat kekeliruan dalam pernikahan; baik kekeliruan tersebut terjadi pada wali yang menikahkannya atau pada suami/isteri yang sesungguhnya haram untuk menikah, baik karena semahram maupun sepesusuan.

Demikian juga dengan anak yang lahir karena keliru bersetubuh dengan pasangan yang ternyata bukan suami atau isterinya yang sah. Anak yang lahir akibat kekeliruan-kekeliruan itu disebut dengan anak syubhat. Bagaimana dengan anak syubhat, siapa yang bertanggungjawab atas anak tersebut dan bagaimana statusnya? Itulah diantara pertanyaan yang harus dicarikan jawabannya.

Kaff dengan judul: Fiqib Lima Mą̧hab, Lentera, Jakarta, 2010, hal. 389. 
Muhammad Jawad Mughniyah menjelaskan bahwa menurut kalangan Sunni, orang yang dilahirkan melalui hubungan syubhat, dia merupakan anak sah sebagaimana halnya dengan anak yang lahir melalui perkawinan yang sah, tanpa ada perbedaan sedikit pun, baik syubhat tersebut merupakan syubhat akad maupun syubhat tindakan. Jadi, barangsiapa yang mencampuri seorang wanita dalam keadaan mabuk, mengigau, gila, dipaksa, atau melakukannya sebelum usia baligh, atau mengira bahwa wanita itu isterinya tapi ternyata bukan, lalu wanita itu melahirkan seorang anak, maka anak itu dikaitkan dengannya. ${ }^{20}$

Menurut Imamiah, nasab yang sah ditetapkan untuk anak tersebut berikut hak-hak yang dimilikinya melalui kesyubhatan tersebut. Kalau orang yang melakukan kesyubhatan itu tidak mengakui anak tersebut, maka hubungan nasab anak itu sama sekali tidak ternafikan, bahkan laki-laki tersebut dipaksa harus mengakuinya. ${ }^{21}$

Dalam kitab al-Ahwal Syakhsiyyah karangan Muhyidin sebagaimana yang dikutip oleh Muhammad Jawad Mughniyah dijelaskan bahwa nasab tidak dapat ditetapkan dengan syubhat macam apapun, kecuali orang yang melakukan syubhat itu mengakuinya, karena ia sebenarnya lebih mengetahui tentang dirinya. Tentang hal yang terakhir ini disepakati oleh para ahli hukum di kalangan sunny dan syiab. ${ }^{22}$

Ulama Sunni dan Syi'i sependapat bahwa, manakala kesyubhatan dengan salah satu pengertiannya di atas telah terjadi, maka si wanita harus menjalani iddah sebagaimana layaknya wanita yang dicerai, sebagaimana halnya dengan kewajiban membayar mahar secara penuh kepadanya. Wanita tersebut dihukumi sebagaimana halnya dengan seorang isteri (yang sah) dalam hal iddah, mahar dan penentuan nasab.

Selanjutnya, menurut Muhammad Jawad Mughniyah, syubhat itu bisa terjadi pada pihak laki-laki dan wanita, yaitu keduanya tidak tahu dan tidak sadar. Tetapi bisa juga terjadi pada salah satu pihak, misalnya si wanitanya tahu bahwa dia punya suami yang sah (dan dia tahu pula bahwa laki-laki yang mencampurinya itu bukan suaminya), tapi dia sembunyikan hal itu terhadap laki-laki tersebut. Atau, si lakilakinya waras, sedangkan si wanitanya gila atau dalam keadaan mabuk. Kalau kesyubhatan tersebut terjadi pada kedua belah pihak, maka anak yang dihasilkan dari hubungan tersebut dikaitkan (nasabnya) pada keduanya. Sedangkan bila hanya terjadi pada salah satu pihak, maka

${ }^{22}$ Ibid., h. 388. 
anak tersebut dikaitkan nasabnya hanya pada orang yang mengalami kesyubhatan, dan ditiadakan dari orang yang tidak mengalaminya. $^{23}$

Betapapun sesungguhnya prinsipprinsip syariat, baik di kalangan Sunni maupun Syi'i, sama-sama menganjurkan tidak diperkenankannya menjatuhkan keputusan terhadap anak manusia yang lahir dari sperma mereka sebagai anak zina (anak haram) sepanjang terbuka kemungkinan untuk menempatkannya sebagai anak syubhat. Kalau hakim mempunyai 99 indikator untuk menetapkan seorang anak sebagai anak zina, dan satu indikator yang menetapkan sebagai anak syubhat, maka dia harus memberlakukan indikator yang disebut terkemudian, dan mencampakkan 99 indikator lainnya itu, dalam rangka merajihkan (mengutamakan) yang halal atas yang haram, yang sah atas yang fasid. ${ }^{24}$

Anak syubhat tetap memiliki hubungan nasab dengan ayahnya jika dalam kasus syubhat pada akad, yakni percampuran antara suami isteri yang ternyata ada hubungan saudara atau susuan. Namun, jika hal tersebut terjadi pada kasus syubhat pada perbuatan, yakni percampuran (watha) yang terjadi antara

Ibid., h. 391.

4 Ibid., h. 389-391.

25 Ibnu Qudamah, Al Mugni, Jilid 9, cet. 1, Darul 'Alamil Kutub, Riyadh, 1986, hal. 528
Fahmi Al-Amruzi

laki-laki dan perempuan karena salah sangka, maka anak itu punya hubungan nasab dengan ayahnya jika sudah diakui sebagai anaknya ${ }^{25}$. Anak syubhat berbeda dengan anak yang dihasilkan karena zina, nasab anak tersebut hanya kepada ibunya.

Mawardi didalam kitabnya Al-Hawa Al-Kabir mengatakan bahwasanya anak syubhat nasabnya tetap pada orang yang menjima'nya, begitu juga warisan, dan menjadi haram dinikahi, yang hukumnya berbeda dengan anak hasil zina. ${ }^{26}$

Apabila watha' syubhat terjadi pada perempuan yang sudah menikah, maka nasab anak yang dilahirkan dilihat dari waktu kelahiran anak tersebut, apabila anak tersebut lahir berjarak enam bulan atau lebih dari saat terjadinya wtha' syubhat itu, maka nasab anak tersebut kepada laki-laki yang melakukan watha' syubhat tersebut, dan sebaliknya apabila kelahiran anak tersebut lahir sebelum enam bulan dari saat terjadi watha' tersebut, maka nasab anak tersebut tetap kepada suaminya. ${ }^{27}$

\section{Hak Anak Syubhat}

Memperhatikan bunyi Pasal 43 ayat (1) UU Nomor 1 Tahun 1974 yang

26 Abi Hasan Ali bin Muhammad bin Habib Al Mawardi, Al Hawi Al Kabir, Juz 9, Cet. 1, Daarul Kutubil Ilmiyah, Libanon, 1994, hal. 219

27 Wahbah Zuhaili, Al Fiqhu Islami Eaadillatuhu, Jilid 9 Cet. 1, Daarul fikr, Damaskus, 1997, hal. 7264 
rumusannya sama dengan Pasal 100 KHI, adalah :

"anak yang labir di luar perkawinan banya mempunyai bubungan nasab dengan ibunya dan keluarga ibunya"

Oleh karenanya anak yang lahir di luar perkawinan hanya mempunyai hubungan perdata dengan ibunya dan keluarga ibunya saja.

Berdasarkan Pasal 43 ayat (1) maupun Pasal 100 KHI diatas, ada beberapa kemungkinan tentang anak dapat dikemukakan sebagai berikut:

1. Anak yang dilahirkan oleh wanita yang tidak mempunyai ikatan perkawinan yang sah dengan pria yang menghamilinya.

2. Anak yang dilahirkan oleh wanita yang kehamilannya akibat korban perkosaan oleh satu orang pria atau lebih.

3. Anak yang dilahirkan oleh wanita yang di li'an (diingkari) oleh suaminya.

4. Anak yang dilahirkan oleh wanita yang kehamilannya akibat salah orang (salah sangka) disangka suaminya ternyata bukan.

5. Anak yang dilahirkan oleh wanita yang kehamilannya akibat pernikahan yang diharamkan seperti menikah dengan saudara kandung atau sepersusuan.

Kemungkinan anak yang tergolong kelompok nomor 4 dan nomor 5 diatas

\section{Fahmi Al-Amruzi}

dalam hukum Islam disebut anak Syubhat yang apabila diakui oleh bapak subhatnya, dan nasabnya dapat dihubungkan kepadanya.

Anak syubhat sesungguhnya adalah anak yang dilahirkan oleh seseorang wanita yang kehamilannya akibat salah orang (salah sangka) disangka suaminya ternyata bukan, atau anak yang dilahirkan oleh wanita yang kehamilannya akibat perkawinan yang difasakh karena sebelumnya tidak diketahui kalau perkawinan tersebut ternyata perkawinan yang diharamkan seperti kawin dengan saudara kandung atau saudara sepesusuan.

Anak tersebut sesungguhnya adalah anak yang lahir diluar dari perkawinan yang sah. Menurut Hukum Perdata: anak yang lahir diluar perkawinan adalah anak yang lahir apabila orang tua anak tersebut tidak terikat perkawinan lain (jejaka, perawan, duda, janda) mereka melakukan hubungan seksual dan melahirkan anak, maka anak tersebut adalah anak luar kawin. Dan apabila orang tua anak tersebut salah satu atau keduanya masih terikat dengan perkawinan lain, kemudian mereka melakukan hubungan seksual dan melahirkan anak, maka anak tersebut adalah anak zina.

Menurut Kompilasi Hukum Islam anak syubhat, dinyatakan sebagai anak yang lahir di luar perkawinan sebagaimana dijelaskan diatas, karenanya anak tersebut 
hanya dihubungkan nasabnya kepada ibunya atau keluarga ibunya saja, kecuali jika ayahnya mengakui sebagai anaknya, maka dapat dihubungkan nasabnya kepadanya.

Status anak tersebut menurut hukum hanya mempunyai hubungan nasab dengan ibunya dan keluarga ibunya semata, maka yang wajib memberikan nafkah anak tersebut adalah ibunya dan keluarga ibunya saja. Sedangkan bagi ayah/bapak alami, meskipun anak tersebut secara biologis merupakan anak yang berasal dari spermanya, namun secara yuridis formal sebagaimana maksud Pasal 100 Kompilasi Hukum Islam di atas, tidak mempunyai kewajiban hukum memberikan nafkah kepada anak tersebut. Hal ini berakibat pula pada hilangnya kewajiban tanggung jawab ayah kepada anak dan hilangnya hak anak kepada ayah.

Dalam kitab "Kanæu al Raghibin”, Imam Jalaludin Muhammad al Mahalli memberikan pernyataan bahwa, menurut Syafi'i, istri yang hamil dari persetubuhan (watha') syubhat, tidak berkewajiban bagi suami untuk memberikan nafkah kepada anak yang lahir dari hubungan syubhat tersebut, sebab ia tidak ada hubungan nasab dengan ayah yang menghamili ibunya. Sedangkan bagi Hanafi, anak tersebut tetap wajib diberi nafkah

28 Imam Jalaludin al Mahalli, Kanzu al Raghibin, (Beirut: Dar al Kutub al Ilmiyah, 2006), h. 126. kepadanya, sebab anak itu walaupun lahir dari hasil watha syubhat, ia tetap berasal dari benih ayahnya sehingga nasabnya pun tetap dihubungkan kepadanya. ${ }^{28}$

Dari keterangan ini, ada dua perbedaan yang mendasar terkait status anak persetubuhan (watha') syubhat.

- Pertama, anak akibat persetubuh- an (watha") syubhat yang nasabnya hanya dihubungkan kepada ibunya dan keluarga ibunya saja. Maka anak ini hanya wajib diberikan nafkah oleh ibunya dan keluarga ibunya, sebab yang dipandang adalah hubungan syubhat yang terjadi antara ibunya dan laki-laki yang menggaulinya, kecuali jika laki-laki tersebut mengakuinya.

- Kedua, anak watha syubhat yang nasabnya tetap dihubungkan kepada kedua orang tuanya. Maka anak ini tetap wajib diberi nafkah oleh kedua orang tuanya sebab yang dipandang adalah bahwa ia dilahirkan dalam status perkawinan terdahulu orang tuanya sebelum difasakh bukan pada hubungan syubhatnya.

Berdasarkan penjelasan yang dikemukakan oleh Muhammad Jawad Mughniyah dapat diketahui bahwa anak yang lahir dari persetubuhan (watha') 
syubhat itu terbagi kepada dua macam, yaitu:

1. Jika kesyubhatan itu terjadi pada kedua belah pihak, maka anak yang hasil dari hubungan mereka adalah statusnya dihukumkan sebagai anak keduanya, sebagaimana pada perkawinan yang sah.

2. Jika kesyubhatan itu terjadi pada salah satu pihak saja, maka anak yang hasil dari hubungan tersebut dikaitkan nasabnya kepada orang yang mengalami kesyubhatan sedangkan pihak yang lain tidak ada kaitan nasab dengannya.

Anak yang lahir dari kesyubhatan yang terjadi dari kedua belah pihak maka akibat hukum yang didapat anak tersebut adalah tetap nasabnya dikaitkan dengan kedua orang tuanya, dan ia berhak mendapatkan nafkah dari keduanya, serta saling waris-mewaris di antara mereka. Sebab pada hakikatnya, ia dilahirkan sama seperti dalam perkawinan yang sah dan tidak termasuk anak zina. Misalnya, anak yang dilahirkan dari perkawinan kedua orang tua yang ternyata memiliki hubungan darah sebab sekandung atau sesusuan tanpa diketahui terlebih dahulu. Maka anak ini tetap wajib diberi nafkah oleh kedua orang tuanya tersebut.

Terhadap nikah syubhat dan kemudian difasakh, menurut Undangundang Perkawinan dan Kompilasi
Hukum Islam: seorang anak yang dilahirkan dari suatu perkawinan, maka status anak itu tetap bernasab atau mempunyai hubungan perdata pada ayah dan ibunya walaupun perkawinan antara ayah dan ibunya tidak sah menurut Undang-undang perkawinan dan Kompilasi Hukum Islam.

Pasal 75 Undang-undanh Nomor 1 Tahun 1974 menjelaskan bahwa "Keputusan pembatalan perkawinan tidak berlaku surut terdap anak-anak yang dilahirkan dari perkawinan tersebut" demikian juga dalam Pasal 28 ayat (2) "Keputusan tidak berlaku surut kepada anak-anak yang dilahirkan dari perkawinan tersebut" Pasal 76 menyebutkan bahwa "Batalnya suatu perkawinan tidak akan memutuskan hubungan hukum antara anak dengan orang tuanya"

Akan tetapi, jika anak yang lahir akibat persetubuhan (watha') syubhat yang terjadi kesyubhatannya pada salah satu pihak saja, maka akibat hukum yang didapat anak itu adalah nasab hanya dikaitkan kepada orang yang mengalami kesyubhatan itu saja, yakni ibu yang melahirkannya dan ia berkewajiban memberikan nafkah kepada anaknya, dan tidak ada kaitan nasab bagi orang yang tidak mengalaminya (pihak laki-laki) sehingga ia pun tidak ada kewajiban dalam memberikan nafkah kepada anak tersebut. Kecuali pihak laki-laki tersebut mengakui 
sebagai anaknya, maka berakibat hukum kepada status nasab anak itu dan nafkahnya dihubungkan kepada ayahnya.

\section{Akibat Hukum Anak Syubhat}

Adalah sebuah keniscayaan ketika terjadi nikah syubhat akan melahirkan anak yang disebut dengan anak syubhat pula. Jika anak syubhat lahir akibat kesyubhatan pada kedua belah pihak statusnya dihukumkan sebagai anak keduanya, sebagaimana pada perkawinan yang sah.

Akan tetapi jika anak syubhat lahir akibat kesyubhatan pada salah satu pihaknya saja maka anak tersebut dihukumkan sebagai anak yang lahir di luar perkawinan. terdapat beberapa akibat hukum terhadap anak tersebut.

a. Nasab

Sebagaimana yang telah diatur dalam Pasal 100 Kompilasi Hukum Islam bahwa anak yang lahir diluar perkawinan hanya mempunyai hubungan nasab dengan ibunya dan keluarga ibunya saja. Hal demikian secara hukum anak tersebut saama sekali tidak dapat dinisbahkan kepada ayah/bapak alaminya, meskipun secara nyata ayah/bapak alami (genetik) tersebut merupakan laki-laki yang menghamili wanita yang melahirkannya itu.

b. Nafkah
Anak syubhat secara hukum tergolong anak yang lahir diluar perkawinan maka status anak tersebut menurut hukum hanya mempunyai hubungan nasab dengan ibunya dan keluarga ibunya semata, oleh karenanya yang wajib memberikan nafkah anak tersebut adalah ibunya dan keluarga ibunya saja. Sedangkan bapak alami (genetik), meskipun anak tersebut secara biologis merupakan anak yang berasal dari spermanya, namun secara yuridis formal sebagaimana maksud Pasal 100 Kompilasi Hukum Islam diatas, tidak mempunyai kewajiban hukum memberikan nafkah kepada anak tersebut.

Berbeda dengan anak sah, bapak dari anak tersebut berkewajiban memberi nafkah dan penghidupan yang layak berupa nafkah, kesehatan, pendidikan dan lainnya kepada anak tersebut sesuai kemampuannya, sebagaimana dijelaskan dalam pasal 80 ayat (4) Kompilasi Hukum Islam, dalam hal ayah dan ibunya masih terikat tali perkawinan. Apabila ayah dan ibu anak tersebut telah bercerai, maka ayah tetap dibebankan memberi nafkah kepada anak-anaknya sesuai dengan kemampuannya, sebagaimana maksud Pasal 105 huruf (c) dan Pasal 156 huruf (d) Kompilasi Hukum Islam.

c. Waris 
Sebagaimana disebutkan dalam Pasal 186 Kompilasi Hukum Islam : “anak yang lahir diluar perkawinan hanya mempunyai hubungan saling mewarisi dengan ibunya dan keluarganya dari pihak ibunya". Dengan demikian, maka anak tersebut secara hukum tidak mempunyai hubungan hukum saling mewarisi dengan ayah/bapak alami (genetiknya). Anak tersebut hanya mempunyai hubungan waris-mewarisi dengan ibunya dan keluarga ibunya saja.

\section{d. Wali}

Apabila anak syubhat yang lahir akibat watha' syubhat berjenis kelamin wanita, dan setelah dewasa anak tersebut akan menikah, maka ayah/bapak alami (genetiknya) tidak berhak atau tidak sah menjadi wali nikahnya, sebab anak syubhat tersebut hanya memiliki nasab dengan ibunya saja dan tidak memiliki nasab dengan bapak genetiknya, oleh karenanya yang berhak menjadi wali terhadap anak tersebut adalah hakim. Berbeda dengan anak syubhat akibat dari perkawinan syubhat, anak yang lahir dari perkawinan syubhat dapat dinisbahkan kepada bapaknya sebab anak tersebut terlahir dalam pernikahan yang sah, baru kemudian perkawinan orang tuanya difasakh karena diketahui terjadi kesyubhatan pada perkawinan tersebut, sebagaimana telah dijelaskan pada bagian terdahulu. Tentang wali nikah dijelaskan dalam Pasal 19, 20 dan 23 Kompilasi hukum Islam.

Pasal 19:

"Wali nikah dalam perkawinan merupakan rukun yang harus dipenuhi bagi calon mempelai wanita yang bertindak untuk menikahkannya".

Pasal 20:

(1) Yang bertindak sebagai wali nikah ialah seorang laki-laki yang memenuhi syarat hukum Islam yakni muslim, aqil dan baligh.

(2) Wali nikah terdiri dari :

a. Wali nasab;

b. Wali hakim

Pasal 23

(1) Wali hakim baru dapat bertindak sebagai wali nikah apabila wali nasab tidak ada atau tidak mungkin menghadirkannya atau tidak diketahui tempat tinggalnya atau gaib atau adlal atau enggan.

\section{Penutup}

Dari Uraian diatas dapat disimpulkan bahwa ada dua perbedaan mendasar terkait status anak syubhat.

1. Anak syubhat akibat perbuatan, nasabnya hanya dihubungkan kepada ibunya dan keluarga ibunya saja. Maka anak ini hanya wajib diberikan nafkah oleh ibunya dan keluarga ibunya, sebab yang dipandang adalah hubungan 
syubhat yang terjadi antara ibunya dan laki-laki yang menggaulinya, kecuali jika laki-laki tersebut mengakuinya.

2. Anak syubhat karena hukum, nasabnya tetap dihubungkan kepada kedua orang tuanya. Maka anak ini tetap wajib diberi nafkah oleh kedua orang tuanya sebab yang dipandang adalah bahwa ia dilahirkan dalam status perkawinan terdahulu orang tuanya sebelum difasakh bukan pada hubungan syubhatnya

\section{Daftar Pustaka}

Abi Hasan Ali bin Muhammad bin Habib Al Mawardi, Al Hawi Al Kabir, Juz 9, Cet. 1, Daarul Kutubil Ilmiyah, Libanon, 1994

AW Munawwir, Al Munawnir Kamus ArabIndonesia, Pustaka Progressif, Yogyakarta, 1984

Beni Ahmad Saebani, Fiqh Munakahat 1, CV. Pustaka Setia, Bandung, 2001

Departemen Agama RI. Kompilasi Hukum Islam, Direktorat Jenderal Pembinaan Kelembagaan Agama Islam, Jakarta, 1998

D.Y. Witanto, Hukum Keluarga Hak dan Kedudukan Anak Luar kawin, Prestasi Pustaka Publisher, Jakarta, 2012

Huzaemah Tahido Yanggo, Fiqih Anak; Metode Islam dalam Mengasub dan
Mendidik Anak serta Hukum-bukum yang Berkaitan dengan Aktivitas Anak, Jakarta: PT. Al-Mawardi Prima, Jakarta, 2005

Ibnu Qudamah, Al Mugni, Jilid 9, cet. 1, Darul 'Alamil Kutub, Riyadh, 1986 Ibnu Mandur, Lisanul arab, Darul Ma'arif, Kairo

Imam Jalaludin al Mahalli, Kan₹u al Raghibin, Dar al Kutub al Ilmiyah, Beirut, 2006

Kementerian Agama Kuwait, Al Mausu'ah Al Fiqhiyah Al Kuwaitiyah, Juz 25, Cet 1, Darus Sahofwah, 1992

Muhammad Jawad Mughniyah, al-Fiqh 'ala al-Madrabib al-Khamsah, diterjemahkan oleh Masykur A.B., Afif Muhammad, dan Idrus alKaff dengan judul: Fiqib Lima Mą̧hab, Lentera, Jakarta, 2010

Rahmat Hakim, Hukum Perkawinan Islam, CV. Pustaka Setia, Bandung 2000

Segaf Hasan Baharun, Bagaimanakah Anda Menikah dan Mengatasi Permasalahannya, Yayasan Pondok Pesantren Darullughah Wadda'wah, Pasuruan, 2005

Sholeh bin Abids Samii' Al-Aaabi AlAzhari Al Aabi Al Azhari, AtsTsamr Ad-Daani fi Tqrïb al-Ma'aani, syarb Risaalah Ibni Abi Zaid AlQoyrowaani, Mushthofa Al-Baabiy Al-Halabi, $1338 \mathrm{~h}$ 
Syekh Hasan Ayyub, Fiqh al Usrah al Muslimah, diterjemahkan oleh Abdul Ghofar EM dengan judul; Fikih Keluarga, Pustaka Al Kautsar, Jakarta, 1999

Undang-Undang Republik Indonesia

Nomor 1 Tahun 1974

TentangPerkawinan, Citra

Umbara, Bandung, 2008

Wahbah Zuhaili, Al Fiqhu Islami Eaadillatuhu, Jilid 9 Cet. 1, Daarul fikr, Damaskus, 1997 